\title{
Deterioration, Compensation and Motor Control Processes in Healthy Aging, Mild Cognitive Impairment and Alzheimer's Disease
}

\author{
Gabriel Poirier ${ }^{1,2, *}$, Alice Ohayon ${ }^{1}$, Adrien Juranville ${ }^{1}$, France Mourey ${ }^{1,2}\left(\mathbb{D}\right.$ and Jeremie Gaveau ${ }^{1,2} \mathbb{D}$ \\ 1 INSERM U1093-CAPS, Université Bourgogne Franche-Comté, UFR des Sciences du Sport, \\ F-21000 Dijon, France; aliceohayon21@gmail.com (A.O.); ajuranvefom@gmail.com (A.J.); \\ France.Mourey@u-bourgogne.fr (F.M.); jeremie.gaveau@u-bourgogne.fr (J.G.) \\ 2 Espace d'Étude du Mouvement-Étienne Jules MAREY, Université Bourgogne Franche-Comté, \\ UFR des Sciences du Sport, F-21000 Dijon, France \\ * Correspondence: gabriel.poirier@u-bourgogne.fr
}

Citation: Poirier, G.; Ohayon, A.; Juranville, A.; Mourey, F.; Gaveau, J. Deterioration, Compensation and Motor Control Processes in Healthy Aging, Mild Cognitive Impairment and Alzheimer's Disease. Geriatrics 2021, 6, 33. https://doi.org/10.3390/ geriatrics6010033

Academic Editor: Craig S. Atwood

Received: 4 March 2021

Accepted: 19 March 2021

Published: 23 March 2021

Publisher's Note: MDPI stays neutral with regard to jurisdictional claims in published maps and institutional affiliations.

Copyright: () 2021 by the authors. Licensee MDPI, Basel, Switzerland. This article is an open access article distributed under the terms and conditions of the Creative Commons Attribution (CC BY) license (https:// creativecommons.org/licenses/by/ $4.0 /)$.

\begin{abstract}
Aging is associated with modifications of several brain structures and functions. These modifications then manifest as modified behaviors. It has been proposed that some brain function modifications may compensate for some other deteriorated ones, thus maintaining behavioral performance. Through the concept of compensation versus deterioration, this article reviews the literature on motor function in healthy and pathological aging. We first highlight mechanistic studies that used paradigms, allowing us to identify precise compensation mechanisms in healthy aging. Subsequently, we review studies investigating motor function in two often-associated neurological conditions, i.e., mild cognitive impairment and Alzheimer's disease. We point out the need to expand the knowledge gained from descriptive studies with studies targeting specific motor control processes. Teasing apart deteriorated versus compensating processes represents precious knowledge that could significantly improve the prevention and rehabilitation of age-related loss of mobility.
\end{abstract}

Keywords: aging; motor control; compensation; deterioration; Alzheimer's; cognition

\section{Introduction}

The proportion of old adults in the world population is growing rapidly [1]. This phenomenon results in an increased prevalence of age-onset neurological conditions, thereby implying a heavy socio-economic burden [2-5]. An important part of this burden is due to mobility impairments [6-8], which have significant repercussions on functional autonomy and predict deleterious health outcomes [9-14]. Effectively improving the prevention and rehabilitation of mobility loss requires a good understanding of motor function in healthy and pathological older populations. This article presents a concise review of the literature on motor function in healthy aging and two often-associated neurological conditions, i.e., mild cognitive impairment (MCI) and Alzheimer's disease (AD). More specifically, this review aims at promoting studies that offer a mechanistic understanding of motor function as an expansion of purely descriptive studies.

\section{Deterioration and Compensation during Healthy Aging}

Studies investigating age-related modifications of motor function have first focused on peripheral neuromuscular factors-see [15] for a review. It is now well known that alteration of the central nervous system (CNS) also significantly contributes to motor dysfunction in older adults [16-19]. Modifications of the CNS can be structural and/or functional $[17,20]$. Structural modifications refer to the degradation of brain structures with aging (e.g., cortical atrophy), while functional modifications denote changes in how these structures operate in the act of motor control. Some functional changes occurring with aging may not systematically be detrimental to motor performance. Some changes 
may correspond to a function degradation, while others may benefit motor performance and represent compensations for function degradations [17,20].

Cabeza et al., (HAROLD model; [21,22]) first raised the concept of functional compensation in older adults. Using positron emission tomography and functional magnetic resonance imagery, these authors investigated brain activations in young and older adults during various cognitive tasks. According to their performances, Cabeza et al. (2002) separated older participants into high- and low-performing groups. Their results showed that whereas pre-frontal cortex recruitment was right-lateralized in young participants and low-performing older adults, it was bilateral in high-performing older adults. The authors proposed that this additional recruitment in high-performing older adults compensates for age-related brain degeneration. Other studies, however, have proposed that such increased brain activity may reflect an inability to select appropriate brain regions [23,24].

Increased brain activation in older individuals is also observed during motor tasks. Increased activation of contralateral motor areas (premotor cortex, primary motor cortex, and supplementary motor area) has been consistently reported [25-32]. Older individuals may also recruit additional cortical and subcortical areas, including the ipsilateral motor cortex, during motor preparation and execution [26-29,31-38]. Some studies suggest that such increased brain activations are nonselective and do not impact behavioral performance (dedifferentiation hypothesis; [17,22,23,33,38-41]). Others, observing significant correlations between brain activations and behavioral performance, support the view that increased activations compensate for age-related deterioration [26-28,37,42-44]. Figure 1 displays a graphical model (adapted from Papegaaij et al. (2014)) of deterioration and compensation mechanisms in aging.

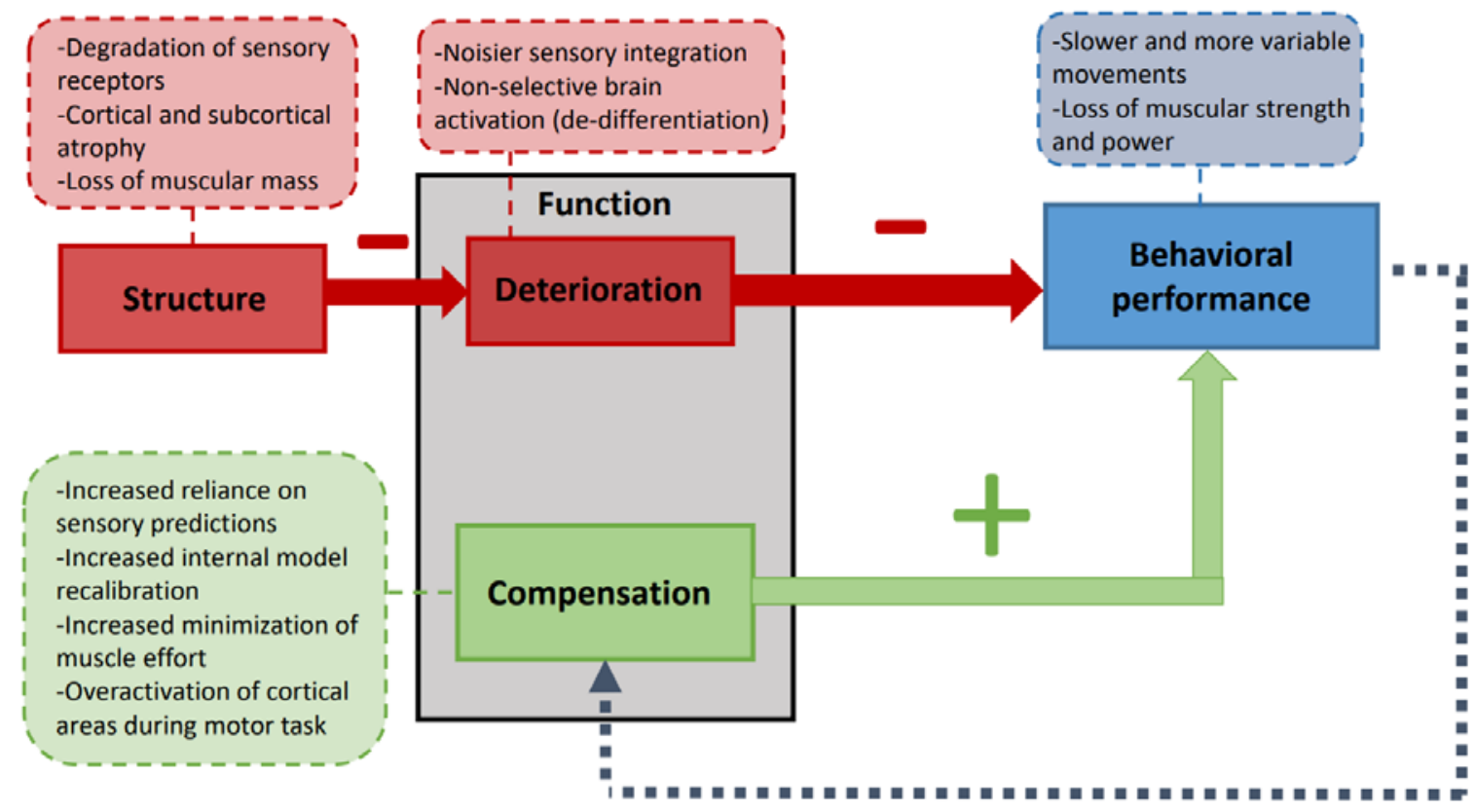

Figure 1. A model of deterioration and compensation of the motor function with aging. Adapted from Papegaaij et al. (2014). Aging alters the structure of the sensorimotor system, causing functional deteriorations (i.e., deterioration in how these structures act during motor tasks) and decreased behavioral motor performances. Decreased performance triggers the need for functional compensations (modifications in how brain structures act to attain motor goals) to maintain behavioral performance. Dashed boxes provide examples of deteriorated and compensating modifications. Examples of age-related structure alterations: degradation of sensory receptors [48-50], cortical atrophy [51-53], and loss of muscular mass [54]. Examples of functional deterioration: noisier sensory integration [48,50] and nonselective brain activation [17,23]. Examples of behavioral modifications: slower and more variable movements [46,47] and loss of muscular strength and power $[45,54]$. Examples of functional compensations: increased reliance on sensory predictions [55-57], increased internal model recalibration [58], increased minimization of muscle effort [59], and overactivation of cortical areas during motor tasks [26]. 
Overall, in the past two decades, the concept of functional motor compensation in older adults has been a controversial subject of several brain imagery and stimulation studies that have investigated brain correlates of motor performance. These performances decline with age due to peripheral neuromuscular as well as central factors $[15,17]$ and include, amongst others, decreased muscle force [45], decreased movement speed [46], and increased variability [47].

\section{Mechanistic Studies of Motor Function in Healthy Aging}

Insofar as modified behavioral performances result from the combination of deteriorated and compensating motor processes in older adults, coarse performance metrics-e.g., force, speed, or precision-are limited in their ability to study compensation mechanisms. They can only measure the net result of compensation and deterioration. It is only recently that behavioral studies have started to consistently and specifically address the concept of functional compensation in older adults. Using paradigms that allowed one to target and isolate specific motor control processes, several studies have highlighted possible compensation mechanisms. Below, we list a few examples.

Wolpe et al. (2016) [55] investigated sensory attenuation - the reduction in the perceived intensity of self-generated actions-via a force-matching task in a population-based cohort ( $n=325 ; 18-88$ years). Results showed increased sensory attenuation in older adults. Furthermore, inter-participant analyses revealed that the size of this effect was proportional to the participants' sensitivity. This result was also associated with measures of the structural and functional connectivity of the pre-supplementary motor area. As increased sensory attenuation suggests a stronger weighting of predictive signals, these results support increased reliance on predictive signals to compensate for noisier sensory signals.

Helsen et al. (2016) [56] investigated the accuracy of wrist-aiming movements with and without visual feedback, along with proprioceptive acuity in young and older adults. Results showed similar accuracy across age groups for visual and non-visual conditions, but older adults exhibited longer movement times and made more corrective sub-movements. Although proprioceptive acuity decreased in older adults, it did not predict aiming behavior. These results also argue for a strategy where older adults increase their reliance on predictive control to compensate for decreased proprioceptive acuity.

Hoellinger et al. (2017) [57] asked young and older adults to make ecological reachgrasp-lift movements with an object whose weight randomly varied across trials. The authors then performed detailed kinematic analysis. Among other results, older adults exhibited shorter movement times and spent more time accelerating than young adults. Theoretical simulations explained these results as a strategy where older adults overestimate the object's weight and preferentially rely on predictive processes to compensate for diminished sensory acuity.

Poirier et al. (2020) [59] investigated vertical arm movements in young and older adults. The authors used a paradigm allowing them to test how motor planning adapts motor patterns to the gravitational environment. Young adults are known to use an optimal strategy that minimizes muscle effort. Directional asymmetries can quantify this strategy, i.e., differences between upward and downward movements [60-63]. Poirier et al. (2020) observed that young and older participants exhibited qualitatively similar directional asymmetries, thereby indicating that older adults can unfold the same effort-related optimization strategy as young adults. Still, the size of the directional asymmetry was more extensive in older participants than in young ones, further suggesting that subtle modifications of effort minimization processes may exist with age. Grounded on previous modeling work about gravity-related optimal motor planning [60-63], increased directional asymmetries in older adults support increased optimization of gravity effects-i.e., increased minimization of muscle effort- to compensate for muscle force decrease. During postural tasks, however, results from other studies may instead support a strategy where older adults emphasize equilibrium maintenance rather than effort minimization [64]. 
Previous studies have shown that aging causes a reduction in motor adaptation [65-70]. It was, however, uncertain whether this decreased motor adaptation was due to explicit (i.e., cognitive) or implicit (i.e., internal model recalibration) components of motor adaptation. Vandevoorde and Orban de Xivry (2019) [58] using paradigms assessing both components and found that reduced motor adaptation is due to a decreased cognitive component in older adults. Internal model recalibration was intact or even increased in older adults. The authors, therefore, proposed that increased internal model recalibration could compensate for the decreased cognitive component.

Such studies offer a deeper understanding of motor control modifications in the aging population. Targeting precise motor control processes demonstrates that some age-related modifications represent compensations for other deteriorated processes. For example, contrary to the ancient view, these studies show that predictive processes are still functional in older adults. In addition, predictive processes seem to be favored over feedback processes to compensate for unreliable sensory signals. Teasing apart deteriorated versus compensating processes represents invaluable knowledge that could significantly improve the prevention and rehabilitation of age-related loss of mobility [9,71]. Such knowledge is also crucial to effectively designing and interpreting neurophysiological investigations [72,73].

\section{Motor Function Studies in Pathological Aging: Alzheimer's Disease (AD) and Mild Cognitive Impairment (MCI)}

$\mathrm{AD}$ is an age-related neurodegenerative disease associated with neurofibrillary tangles and amyloid plaques, causing loss of memory, general cognitive decline, and eventually dementia. The onset of AD may be preceded by $\mathrm{MCI}$, known as a transitional stage between healthy aging and $\mathrm{AD}$ and characterized by soft cognitive symptoms that do not functionally impact daily life [74]. These pathologies have long been considered as pathologies that mostly affect cognitive functions. It is now notoriously known that mobility capacities also are worse in $\mathrm{AD}$ and $\mathrm{MCI}$ populations than age-matched cognitively unimpaired older adults. Overall, studies have reported slower gait speed, as well as a shorter and more variable stride [75-87]. Balance and postural control are also impaired [77,78,88-95], and kinematic studies investigating handwriting and finger-tapping movements have reported fine motor control deterioration in MCI and AD patients [96-100].

The cognitive neuroscience concept of reserve, maintenance, and compensation [101] and cognition-action theories [17] can propose a possible explanation for the motor decline in $\mathrm{AD}$ and MCI. Reserve is the accumulation of brain resources during the life span, maintenance is the preservation of these resources via constant recovery, and compensation is the deployment of new resources to execute a given constant task demand. The inability to compensate for age-related degeneration could be framed as a lack of reserves or their deterioration. Some studies suggest that higher cognitive reserves delay the onset of cognitive symptoms in $\mathrm{AD}[102,103]$. These reserves may compensate for brain degeneration at the beginning of the pathology, but with the progression of deterioration, reserves become insufficient to compensate for the pathology's effects. Thus, compensation is no longer possible, and symptoms appear. A parallel can be made for motor control deteriorations in $\mathrm{AD}$ and $\mathrm{MCI}$. As brain reserves decline, age-related changes can no longer be compensated and become more salient (see Figure 1). Evidence showing that cognitive and motor regions are functionally interdependent supports this view [104]. During challenging motor tasks, older adults also recruit additional brain regions that were viewed as mainly cognitive regions $[28,105]$. The strengthening of reserves therefore seems essential in the prevention of pathological aging. The simultaneous execution of a motor and a cognitive task is an excellent example of what can be tested during aging to probe the evolution of cognition-action interactions and inform geriatric rehabilitation [106].

Studies have shown that modifications of sensorimotor functions may precede the onset of dementia $[91,107,108]$ and that the presence of motor dysfunction could predict adverse outcomes in AD patients, such as fall risk [9-14,84,85,108-111]. In MCI, studies have also reported that motor function impairments are predictive of a higher risk of devel- 
oping AD [79,98,108,112]. Aggarwal et al. (2006) investigated lower limb motor function in an aged longitudinal cohort study. They quantified lower limb performance with an index, including walking speed, sit-to-stand speed, and balance time on unipodal and bipodal tests. Lower performance was associated with an increased risk of developing AD.

Because motor deficits, or at least their detection, seem to precede cognitive impairment, one could use them as predictive diagnostic tools $[84,91,98,113]$. For example, in a recent study, Ehsani et al. (2020) asked MCI patients, AD patients, and healthy controls to execute repetitive elbow flexion on a dual task (counting backward by ones and threes). Logistic ordinal models were able to predict the different groups' cognitive status from measures of elbow angle variability and angular velocity. These models had good sensitivity and specificity and, thus, could be used to detect cognitive impairment in older adults. Such tools could also predict cognitive capacities' evolution [98,108,114-116]. For example, Chou et al., 2019 [117] evaluated the handgrip strength and gait speed of participants aged 60 and over. Over a 10-year period, they correlated the results with those of cognitive tests (the Mini-Mental Score Examination and the Digit Symbol Substitution Test). Motor measures were effective at predicting cognitive decline. All these results demonstrate motor control impairments in AD and MCI patients. They also show that studying these impairments is of particular interest for diagnosis purposes. These studies, however, mostly assessed global motor function rather than specific motor control processes. Thus, they can mostly observe the net result of degraded and compensating processes.

\section{Final Remarks and Futures Perspectives}

As illustrated above with regard to healthy aging, studying motor control processes could allow a precious understanding of compensation versus deterioration mechanisms. In addition, in pathological aging, this could (i) improve the efficacy of sensorimotor measures for diagnosis purposes, (ii) inform prevention programs about the loss of mobility, (iii) benefit personalized medicine for frail older adults who notoriously present with heterogeneous deficiencies [118], and (iv) generate new hypotheses about the physiopathology/etiology of neurological diseases. There is a growing literature probing specific motor control processes in healthy aging but a critical lack of such studies on pathological aging. Building future studies within the deterioration versus compensation framework may strongly benefit aging research and care. It is urgent to promote such studies [72].

Author Contributions: Conceptualization, G.P. and J.G.; writing-original draft preparation, G.P. and A.O.; writing-review and editing, G.P., A.O., A.J., F.M., J.G.; All authors have read and agreed to the published version of the manuscript.

Funding: This work was supported by the Institut National de la Santé et de la Recherche Médicale (INSERM and the French "Investissements d'Avenir" program, project ISITE-BFC (contract ANR-15IDEX-0003).

Institutional Review Board Statement: Not applicable.

Informed Consent Statement: Not applicable.

Data Availability Statement: Not applicable.

Conflicts of Interest: The authors declare no conflict of interest.

\section{References}

1. World Population Prospects-Population Division-United Nations. Available online: https://population.un.org/wpp/ Download/Standard/Population/ (accessed on 24 February 2021).

2. Wimo, A.; Jönsson, L.; Bond, J.; Prince, M.; Winblad, B. Alzheimer Disease International The worldwide economic impact of dementia 2010. Alzheimer's Dement. 2013, 9, 1-11.e3. [CrossRef]

3. Takizawa, C.; Thompson, P.L.; Van Walsem, A.; Faure, C.; Maier, W.C. Epidemiological and Economic Burden of Alzheimer's Disease: A Systematic Literature Review of Data across Europe and the United States of America. J. Alzheimer's Dis. 2014, 43, 1271-1284. [CrossRef] 
4. Jia, J.; Wei, C.; Chen, S.; Li, F.; Tang, Y.; Qin, W.; Zhao, L.; Jin, H.; Xu, H.; Wang, F.; et al. The cost of Alzheimer's disease in China and re-estimation of costs worldwide. Alzheimer's Dement. 2018, 14, 483-491. [CrossRef]

5. Hardy, S.E.; Kang, Y.; Studenski, S.A.; Degenholtz, H.B. Ability to Walk $1 / 4$ Mile Predicts Subsequent Disability, Mortality, and Health Care Costs. J. Gen. Intern. Med. 2011, 26, 130. [CrossRef]

6. Cummings, S.R.; Studenski, S.; Ferrucci, L. A Diagnosis of Dismobility-Giving Mobility Clinical Visibility: A Mobility Working Group Recommendation. JAMA J. Am. Med Assoc 2014, 311, 2061-2062. [CrossRef]

7. Musich, S.; Wang, S.S.; Ruiz, J.; Hawkins, K.; Wicker, E. The impact of mobility limitations on health outcomes among older adults. Geriatr. Nurs. 2018, 39, 162-169. [CrossRef]

8. Shumway-Cook, A.; Ciol, M.A.; Yorkston, K.M.; Hoffman, J.M.; Chan, L. Mobility Limitations in the Medicare Population: Prevalence and Sociodemographic and Clinical Correlates. J. Am. Geriatr. Soc. 2005, 53, 1217-1221. [CrossRef] [PubMed]

9. Ferrucci, L.; Cooper, R.; Shardell, M.; Simonsick, E.M.; Schrack, J.A.; Kuh, D. Age-Related Change in Mobility: Perspectives From Life Course Epidemiology and Geroscience. J. Gerontol. Ser. A Boil. Sci. Med Sci. 2016, 71, 1184-1194. [CrossRef]

10. Studenski, S.; Perera, S.; Patel, K.; Rosano, C.; Faulkner, K.; Inzitari, M.; Brach, J.; Chandler, J.; Cawthon, P.; Connor, E.B.; et al. Gait Speed and Survival in Older Adults. JAMA J. Am. Med. Assoc. 2011, 305, 50. [CrossRef] [PubMed]

11. Vermeulen, J.; Neyens, J.C.L.; Van Rossum, E.; Spreeuwenberg, M.D.; De Witte, L.P. Predicting ADL disability in communitydwelling elderly people using physical frailty indicators: A systematic review. BMC Geriatr. 2011, 11, 33. [CrossRef]

12. Newman, A.B.; Simonsick, E.M.; Naydeck, B.L.; Boudreau, R.M.; Kritchevsky, S.B.; Nevitt, M.C.; Pahor, M.; Satterfield, S.; Brach, J.S.; Studenski, S.A.; et al. Association of Long-Distance Corridor Walk Performance With Mortality, Cardiovascular Disease, Mobility Limitation, and Disability. JAMA 2006, 295, 2018-2026. [CrossRef] [PubMed]

13. Montero-Odasso, M.M.; Barnes, B.; Speechley, M.; Hunter, S.W.M.; Doherty, T.J.; Duque, G.; Gopaul, K.; Sposato, L.A.; CasasHerrero, A.; Borrie, M.J.; et al. Disentangling Cognitive-Frailty: Results From the Gait and Brain Study. J. Gerontol. Ser. A Boil. Sci. Med. Sci. 2016, 71, 1476-1482. [CrossRef]

14. Verghese, J.; Wang, C.; Lipton, R.B.; Holtzer, R. Motoric Cognitive Risk Syndrome and the Risk of Dementia. J. Gerontol. Ser. A Boil. Sci. Med Sci. 2013, 68, 412-418. [CrossRef]

15. Hunter, S.K.; Pereira, H.M.; Keenan, K.G. The aging neuromuscular system and motor performance. J. Appl. Physiol. 2016, 121, 982-995. [CrossRef]

16. Clark, B.C.; Woods, A.J.; Clark, L.A.; Criss, C.R.; Shadmehr, R.; Grooms, D.R. The Aging Brain \& the Dorsal Basal Ganglia: Implications for Age-Related Limitations of Mobility. Adv. Geriatr. Med. Res. 2019, 1. [CrossRef]

17. Seidler, R.D.; Bernard, J.A.; Burutolu, T.B.; Fling, B.W.; Gordon, M.T.; Gwin, J.T.; Kwak, Y.; Lipps, D.B. Motor control and aging: Links to age-related brain structural, functional, and biochemical effects. Neurosci. Biobehav. Rev. 2010, 34, 721-733. [CrossRef] [PubMed]

18. Sorond, F.A.; Cruz-Almeida, Y.; Clark, D.J.; Viswanathan, A.; Scherzer, C.R.; De Jager, P.; Csiszar, A.; Laurienti, P.J.; Hausdorff, J.M.; Chen, W.G.; et al. Aging, the Central Nervous System, and Mobility in Older Adults: Neural Mechanisms of Mobility Impairment. J. Gerontol. Ser. A Boil. Sci. Med. Sci. 2015, 70, 1526-1532. [CrossRef]

19. Rosso, A.L.; Studenski, S.A.; Chen, W.G.; Aizenstein, H.J.; Alexander, N.B.; Bennett, D.A.; Black, S.E.; Camicioli, R.; Carlson, M.C.; Ferrucci, L.; et al. Aging, the Central Nervous System, and Mobility. J. Gerontol. Ser. A Boil. Sci. Med. Sci. 2013, 68, 1379-1386. [CrossRef] [PubMed]

20. Papegaaij, S.; Taube, W.; Baudry, S.; Otten, E.; Hortobágyi, T. Aging Causes a Reorganization of Cortical and Spinal Control of Posture. Front. Aging Neurosci. 2014, 6, 28. [CrossRef] [PubMed]

21. Cabeza, R.; Anderson, N.D.; Locantore, J.K.; McIntosh, A.R. Aging Gracefully: Compensatory Brain Activity in High-Performing Older Adults. Neuroimage 2002, 17, 1394. [CrossRef]

22. Cabeza, R. Hemispheric Asymmetry Reduction in Older Adults: The HAROLD Model. Psychol. Aging 2002, 17, 85. [CrossRef]

23. Logan, J.M.; Sanders, A.L.; Snyder, A.Z.; Morris, J.C.; Buckner, R.L. Under-Recruitment and Nonselective Recruitment: Dissociable Neural Mechanisms Associated with Aging. Neuronology 2002, 33, 827.

24. Buckner, R.; Logan, J.M. Frontal Contributions to Episodic Memory Encoding in the Young and Elderly. Cogn. Neurosci. Mem. Encoding Retr. 2002, 59.

25. Wang, L.; Zhang, Y.; Zhang, J.; Sang, L.; Li, P.; Yan, R.; Qiu, M.; Liu, C. Aging Changes Effective Connectivity of Motor Networks During Motor Execution and Motor Imagery. Front. Aging Neurosci. 2019, 11, 312. [CrossRef]

26. Mattay, V.; Fera, F.; Tessitore, A.; Hariri, A.; Das, S.; Callicott, J.; Weinberger, D. Neurophysiological correlates of age-related changes in human motor function. Neurology 2002, 58, 630-635. [CrossRef] [PubMed]

27. Ward, N.S.; Frackowiak, R.S.J. Age-related changes in the neural correlates of motor performance. Brain 2003, 126, 873-888. [CrossRef] [PubMed]

28. Heuninckx, S.; Wenderoth, N.; Swinnen, S.P. Systems Neuroplasticity in the Aging Brain: Recruiting Additional Neural Resources for Successful Motor Performance in Elderly Persons. J. Neurosci. 2008, 28, 91-99. [CrossRef] [PubMed]

29. Heuninckx, S.; Wenderoth, N.; Debaere, F.; Peeters, R.; Swinnen, S.P. Neural Basis of Aging: The Penetration of Cognition into Action Control. J. Neurosci. 2005, 25, 6787-6796. [CrossRef] [PubMed]

30. Turesky, T.K.; Turkeltaub, P.E.; Eden, G.F. An Activation Likelihood Estimation Meta-Analysis Study of Simple Motor Movements in Older and Young Adults. Front. Aging Neurosci. 2016, 8, 238. [CrossRef] 
31. McGregor, K.M.; Craggs, J.G.; Benjamin, M.L.; Crosson, B.; White, K.D. Age-Related Changes in Motor Control During Unimanual Movements. Brain Imaging Behav. 2009, 3, 317-331. [CrossRef]

32. Hutchinson, S.; Kobayashi, M.; Horkan, C.M.; Pascual-Leone, A.; Alexander, M.P.; Schlaug, G. Age-Related Differences in Movement Representation. Neuroimage 2002, 17, 1720. [CrossRef]

33. Ward, N.S.; Swayne, O.B.; Newton, J.M. Age-dependent changes in the neural correlates of force modulation: An fMRI study. Neurobiol. Aging 2008, 29, 1434-1446. [CrossRef]

34. Calautti, C.; Serrati, C.; Baron, J.C. Effects of Age on Brain Activation during Auditory-Cued Thumb-to-Index Opposition: A Positron Emission Tomography Study. Stroke 2001, 32, 139. [CrossRef] [PubMed]

35. Langan, J.; Peltier, S.J.; Bo, J.; Fling, B.W.; Welsh, R.C.; Seidler, R.D. Functional implications of age differences in motor system connectivity. Front. Syst. Neurosci. 2010, 4, 17. [CrossRef] [PubMed]

36. Boudrias, M.-H.; Gonçalves, C.S.; Penny, W.D.; Park, C.-H.; Rossiter, H.E.; Talelli, P.; Ward, N.S. Age-related changes in causal interactions between cortical motor regions during hand grip. NeuroImage 2012, 59, 3398-3405. [CrossRef] [PubMed]

37. Naccarato, M.; Calautti, C.; Jones, P.; Day, D.; Carpenter, T.; Baron, J.-C. Does healthy aging affect the hemispheric activation balance during paced index-to-thumb opposition task? An fMRI study. NeuroImage 2006, 32, 1250-1256. [CrossRef]

38. Riecker, A.; Gröschel, K.; Ackermann, H.; Steinbrink, C.; Witte, O.; Kastrup, A. Functional significance of age-related differences in motor activation patterns. NeuroImage 2006, 32, 1345-1354. [CrossRef]

39. Bernard, J.A.; Seidler, R.D. Evidence for motor cortex dedifferentiation in older adults. Neurobiol. Aging 2012, 33, 1890-1899. [CrossRef]

40. Park, D.C.; Polk, T.A.; Park, R.; Minear, M.; Savage, A.; Smith, M.R. From The Cover: Aging reduces neural specialization in ventral visual cortex. Proc. Natl. Acad. Sci. USA 2004, 101, 13091-13095. [CrossRef]

41. Li, S.-C. Lindenberger, Cross-Level Unification: A Computational Exploration of the Link between Deterioration of Neurotransmitter Systems and Dedifferentiation of Cognitive Abilities in Old Age. In Cognitive Neuroscience of Memory; Hogrefe \& Huber: Toronto, ON, Canada, 1999; pp. 103-146.

42. Harada, T.; Miyai, I.; Suzuki, M.; Kubota, K. Gait capacity affects cortical activation patterns related to speed control in the elderly. Exp. Brain Res. 2009, 193, 445-454. [CrossRef]

43. Reuter-Lorenz, P.A.; Lustig, C. Brain aging: Reorganizing discoveries about the aging mind. Curr. Opin. Neurobiol. 2005, 15, 245-251. [CrossRef]

44. Wu, T.; Hallett, M. The influence of normal human ageing on automatic movements. J. Physiol. 2005, 562, 605-615. [CrossRef]

45. Pousson, M.; Lepers, R.; Van Hoecke, J. Changes in isokinetic torque and muscular activity of elbow flexors muscles with age. Exp. Gerontol. 2001, 36, 1687-1698. [CrossRef]

46. Buckles, V.D. Age-Related Slowing. In Sensorimotor Impairment in the Elderly; Metzler, J.B., Ed.; Springer: Dordrecht, The Netherlands, 1993; pp. 73-87.

47. Darling, W.; Cooke, J.; Brown, S. Control of simple arm movements in elderly humans. Neurobiol. Aging 1989, 10, 149-157. [CrossRef]

48. Goble, D.J.; Coxon, J.P.; Wenderoth, N.; Van Impe, A.; Swinnen, S.P. Proprioceptive sensibility in the elderly: Degeneration, functional consequences and plastic-adaptive processes. Neurosci. Biobehav. Rev. 2009, 33, 271-278. [CrossRef]

49. Zalewski, C.K. Aging of the Human Vestibular System. Semin. Hear. 2015, 36, 175-196. [CrossRef] [PubMed]

50. Saftari, L.N.; Kwon, O.-S. Ageing vision and falls: A review. J. Physiol. Anthr. 2018, 37, 11. [CrossRef] [PubMed]

51. Hoffstaedter, F.; Grefkes, C.; Roski, C.; Caspers, S.; Zilles, K.; Eickhoff, S.B. Age-related decrease of functional connectivity additional to gray matter atrophy in a network for movement initiation. Beiträge Ref. Anat. Entwickelungsgeschichte 2015, 220, 999-1012. [CrossRef]

52. Salat, D.H.; Buckner, R.L.; Snyder, A.Z.; Greve, D.N.; Desikan, R.S.R.; Busa, E.; Morris, J.C.; Dale, A.M.; Fischl, B. Thinning of the Cerebral Cortex in Aging. Cereb. Cortex 2004, 14, 721-730. [CrossRef]

53. Buss, C.; Rasmussen, J.; Bischof, G.N.; Sele, S.; Jäncke, L.; Liem, F.; Mérillat, S. Decline Variability of Cortical and Subcortical Regions in Aging: A Longitudinal Study. Front. Hum. Neurosci. 2020, 14, 363.

54. Larsson, L.; Degens, H.; Li, M.; Salviati, L.; Lee, Y.I.; Thompson, W.; Kirkland, J.L.; Sandri, M. Sarcopenia: Aging-Related Loss of Muscle Mass and Function. Physiol. Rev. 2019, 99, 427-511. [CrossRef]

55. Wolpe, N.; Can, C.-; Ingram, J.N.; Tsvetanov, K.A.; Geerligs, L.; Kievit, R.A.; Henson, R.N.; Wolpert, D.M.; Rowe, J.B. Ageing increases reliance on sensorimotor prediction through structural and functional differences in frontostriatal circuits. Nat. Commun. 2016, 7, 13034. [CrossRef]

56. Helsen, W.F.; Van Halewyck, F.; Levin, O.; Boisgontier, M.P.; Lavrysen, A.; Elliott, D. Manual aiming in healthy aging: Does proprioceptive acuity make the difference? AGE 2016, 38, 1-19. [CrossRef]

57. Hoellinger, T.; McIntyre, J.; Jami, L.; Hanneton, S.; Cheron, G.; Roby-Brami, A. A strategy of faster movements used by elderly humans to lift objects of increasing weight in ecological context. Neuroscience 2017, 357, 384-399. [CrossRef] [PubMed]

58. Vandevoorde, K.; Orban de Xivry, J.J. Internal Model Recalibration Does Not Deteriorate with Age While Motor Adaptation Does. Neurobiol. Aging 2019, 80, 138. [CrossRef] [PubMed]

59. Poirier, G.; Papaxanthis, C.; Mourey, F.; Gaveau, J. Motor Planning of Vertical Arm Movements in Healthy Older Adults: Does Effort Minimization Persist With Aging? Front. Aging Neurosci. 2020, 12, 37. [CrossRef] 
60. Berret, B.; Darlot, C.; Jean, F.; Pozzo, T.; Papaxanthis, C.; Gauthier, J.P. The Inactivation Principle: Mathematical Solutions Minimizing the Absolute Work and Biological Implications for the Planning of Arm Movements. PLoS Comput. Biol. 2008, 4, e1000194. [CrossRef]

61. Gaveau, J.; Berret, B.; Demougeot, L.; Fadiga, L.; Pozzo, T.; Papaxanthis, C. Energy-related optimal control accounts for gravitational load: Comparing shoulder, elbow, and wrist rotations. J. Neurophysiol. 2014, 111, 4-16. [CrossRef] [PubMed]

62. Gaveau, J.; Berret, B.; E Angelaki, D.; Papaxanthis, C. Direction-dependent arm kinematics reveal optimal integration of gravity cues. eLife 2016, 5, e16394. [CrossRef]

63. Gaveau, J.; Grospretre, S.; Angelaki, D.; Papaxanthis, C. A Cross-Species Neural Integration of Gravity for Motor Optimisation. BioRxiv 2019, 728857.

64. Casteran, M.; Hilt, P.M.; Mourey, F.; Manckoundia, P.; French, R.; Thomas, E. Shifts in Key Time Points and Strategies for a Multisegment Motor Task in Healthy Aging Subjects. J. Gerontol. Ser. A Boil. Sci. Med. Sci. 2018, 73, 1609-1617. [CrossRef]

65. Bock, O. Components of sensorimotor adaptation in young and elderly subjects. Exp. Brain Res. 2004, 160, 259-263. [CrossRef]

66. Buch, E.R.; Young, S.; Contreras-Vidal, J.L. Visuomotor Adaptation in Normal Aging. Learn. Mem. 2003, 10, 55-63. [CrossRef]

67. Anguera, J.A.; Reuter-Lorenz, P.A.; Willingham, D.T.; Seidler, R.D. Failure to Engage Spatial Working Memory Contributes to Age-related Declines in Visuomotor Learning. J. Cogn. Neurosci. 2011, 23, 11-25. [CrossRef] [PubMed]

68. Bock, O.; Girgenrath, M. Relationship between sensorimotor adaptation and cognitive functions in younger and older subjects. Exp. Brain Res. 2005, 169, 400-406. [CrossRef] [PubMed]

69. Hegele, M.; Heuer, H. Adaptation to a direction-dependent visuomotor gain in the young and elderly. Psychol. Res. 2008, 74, 21-34. [CrossRef]

70. King, B.R.; Fogel, S.M.; Albouy, G.; Doyon, J. Neural correlates of the age-related changes in motor sequence learning and motor adaptation in older adults. Front. Hum. Neurosci. 2013, 7, 142. [CrossRef] [PubMed]

71. Martínez-Velilla, N.; Casas-Herrero, A.; Zambom-Ferraresi, F.; Sáez De Asteasu, M.L.; Lucia, A.; Galbete, A.; García-Baztán, A.; Alonso-Renedo, J.; González-Glaría, B.; Gonzalo-Lázaro, M.; et al. Effect of Exercise Intervention on Functional Decline in Very Elderly Patients During Acute Hospitalization: A Randomized Clinical Trial. JAMA Intern. Med. 2019, 179, 28. [CrossRef] [PubMed]

72. Krakauer, J.W.; Ghazanfar, A.A.; Gomez-Marin, A.; MacIver, M.A.; Poeppel, D. Neuroscience Needs Behavior: Correcting a Reductionist Bias. Neuron 2017, 93, 480-490. [CrossRef]

73. Angelaki, D.E.; Gu, Y.; DeAngelis, G.C. Multisensory integration: Psychophysics, neurophysiology, and computation. Curr. Opin. Neurobiol. 2009, 19, 452-458. [CrossRef]

74. Petersen, R.C.; Caracciolo, B.; Brayne, C.; Gauthier, S.; Jelic, V.; Fratiglioni, L. Mild cognitive impairment: A concept in evolution. J. Intern. Med. 2014, 275, 214-228. [CrossRef]

75. Verghese, J.; Robbins, M.; Holtzer, R.; Zimmerman, M.; Wang, C.; Xue, X.; Lipton, R.B. Gait Dysfunction in Mild Cognitive Impairment Syndromes. J. Am. Geriatr. Soc. 2008, 56, 1244-1251. [CrossRef] [PubMed]

76. Montero-Odasso, M.; Muir, S.W.; Speechley, M. Dual-Task Complexity Affects Gait in People With Mild Cognitive Impairment: The Interplay Between Gait Variability, Dual Tasking, and Risk of Falls. Arch. Phys. Med. Rehabil. 2012, 93, 293-299. [CrossRef]

77. Suttanon, P.; Hill, K.D.; Said, C.M.; Dodd, K.J. A Longitudinal Study of Change in Falls Risk and Balance and Mobility in Healthy Older People and People with Alzheimer Disease. Am. J. Phys. Med. Rehabil. 2013, 92, 676-685. [CrossRef]

78. Suttanon, P.; Hill, K.D.; Said, C.M.; LoGiudice, D.; Lautenschlager, N.T.; Dodd, K.J. Balance and Mobility Dysfunction and Falls Risk in Older People with Mild to Moderate Alzheimer Disease. Am. J. Phys. Med. Rehabil. 2012, 91, 12-23. [CrossRef] [PubMed]

79. Wu, Q.; Chan, J.S.; Yan, J.H. Mild cognitive impairment affects motor control and skill learning. Rev. Neurosci. 2016, 27, 197-217. [CrossRef] [PubMed]

80. Montero-Odasso, M.; Oteng-Amoako, A.; Speechley, M.; Gopaul, K.; Beauchet, O.; Annweiler, C.; Muir-Hunter, S.W. The Motor Signature of Mild Cognitive Impairment: Results From the Gait and Brain Study. J. Gerontol. Ser. A Boil. Sci. Med. Sci. 2014, 69, 1415-1421. [CrossRef] [PubMed]

81. Boripuntakul, S.; Lord, S.R.; Brodie, M.A.D.; Smith, S.T.; Methapatara, P.; Wongpakaran, N.; Sungkarat, S. Spatial variability during gait initiation while dual tasking is increased in individuals with mild cognitive impairment. J. Nutr. Health Aging 2013, 18, 307-312. [CrossRef]

82. Doi, T.; Shimada, H.; Makizako, H.; Tsutsumimoto, K.; Uemura, K.; Anan, Y.; Suzuki, T. Cognitive function and gait speed under normal and dual-task walking among older adults with mild cognitive impairment. BMC Neurol. 2014, 14, 67. [CrossRef]

83. Tarnanas, I.; Papagiannopoulos, S.; Kazis, D.; Wiederhold, M.; Widerhold, B.; Tsolaki, M. Reliability of a novel serious game using dual-task gait profiles to early characterize aMCI. Front. Aging Neurosci. 2015, 7, 50. [CrossRef]

84. Pau, M.; Mulas, I.; Putzu, V.; Asoni, G.; Viale, D.; Mameli, I.; Leban, B.; Allali, G. Smoothness of Gait in Healthy and Cognitively Impaired Individuals: A Study on Italian Elderly Using Wearable Inertial Sensor. Sensors 2020, 20, 3577. [CrossRef]

85. Gillain, S.; Warzee, E.; Lekeu, F.; Wojtasik, V.; Maquet, D.; Croisier, J.L.; Salmon, E.; Petermans, J. The Value of Instrumental Gait Analysis in Elderly Healthy, MCI or Alzheimer's Disease Subjects and a Comparison with Other Clinical Tests Used in Single and Dual-Task Conditions. Ann. Phys. Rehabil. Med. 2009, 52, 453. [CrossRef] [PubMed]

86. Maquet, D.; Lekeu, F.; Warzee, E.; Gillain, S.; Wojtasik, V.; Salmon, E.; Petermans, J.; Croisier, J.L. Gait Analysis in Elderly Adult Patients with Mild Cognitive Impairment and Patients with Mild Alzheimer's Disease: Simple versus Dual Task: A Preliminary Report. Clin. Physiol. Funct. Imaging 2010, 30, 51. [CrossRef] 
87. Choi, J.S.; Oh, H.S.; Kang, D.W.; Mun, K.R.; Choi, M.H.; Lee, S.J.; Yang, J.W.; Chung, S.C.; Mun, S.W.; Tack, G.R. Comparison of Gait and Cognitive Function among the Elderly with Alzheimer's Disease, Mild Cognitive Impairment and Healthy. Int. J. Precis. Eng. Manuf. 2011, 12, 169. [CrossRef]

88. Deschamps, T.; Beauchet, O.; Annweiler, C.; Cornu, C.; Mignardot, J.-B. Postural control and cognitive decline in older adults: Position versus velocity implicit motor strategy. Gait Posture 2014, 39, 628-630. [CrossRef]

89. Jeon, S.Y.; Han, S.J.; Jeong, J.H.; Fregni, F. Effect of exercise on balance in persons with mild cognitive impairment. Neurorehability 2014, 35, 271-278. [CrossRef]

90. Tangen, G.G.; Engedal, K.; Bergland, A.; Moger, T.A.; Mengshoel, A.M. Relationships Between Balance and Cognition in Patients With Subjective Cognitive Impairment, Mild Cognitive Impairment, and Alzheimer Disease. Phys. Ther. 2014, 94, 1123-1134. [CrossRef]

91. Bahureksa, L.; Najafi, B.; Saleh, A.; Sabbagh, M.; Coon, D.; Mohler, M.J.; Schwenk, M. The Impact of Mild Cognitive Impairment on Gait and Balance: A Systematic Review and Meta-Analysis of Studies Using Instrumented Assessment. Gerontology 2017, 63, 67-83. [CrossRef] [PubMed]

92. Sparto, P.J.; Rosso, A.L.; Divecha, A.A.; Metti, A.L.; Rosano, C. Shared neural substrates of cognitive function and postural control in older adults. Alzheimer's Dement. 2020, 16, 621-629. [CrossRef]

93. Gras, L.Z.; Kanaan, S.F.; McDowd, J.M.; Colgrove, Y.M.; Burns, J.; Pohl, P.S. Balance and Gait of Adults With Very Mild Alzheimer Disease. J. Geriatr. Phys. Ther. 2015, 38, 1-7. [CrossRef]

94. Jor'Dan, A.J.; McCarten, J.R.; Rottunda, S.; Stoffregen, T.A.; Manor, B.; Wade, M.G. Dementia alters standing postural adaptation during a visual search task in older adult men. Neurosci. Lett. 2015, 593, 101-106. [CrossRef]

95. Lee, Y.-W.; Lee, H.; Chung, I.-S.; Yi, H.-A. Relationship between postural instability and subcortical volume loss in Alzheimer's disease. Medicine 2017, 96, e7286. [CrossRef]

96. Yan, J.H.; Rountree, S.; Massman, P.; Doody, R.S.; Li, H. Alzheimer's disease and mild cognitive impairment deteriorate fine movement control. J. Psychiatr. Res. 2008, 42, 1203-1212. [CrossRef]

97. Schröter, A.; Mergl, R.; Bürger, K.; Hampel, H.; Möller, H.-J.; Hegerl, U. Kinematic Analysis of Handwriting Movements in Patients with Alzheimer's Disease, Mild Cognitive Impairment, Depression and Healthy Subjects. Dement. Geriatr. Cogn. Disord. 2003, 15, 132. [CrossRef] [PubMed]

98. Buracchio, T.; Dodge, H.H.; Howieson, D.B.; Wasserman, D.; Kaye, J. The Trajectory of Gait Speed Preceding Mild Cognitive Impairment. Arch. Neurol. 2010, 67, 980-986. [CrossRef] [PubMed]

99. Bangert, A.S.; Balota, D.A. Keep Up the Pace: Declines in Simple Repetitive Timing Differentiate Healthy Aging from the Earliest Stages of Alzheimer's Disease. J. Int. Neuropsychol. Soc. 2012, 18, 1052-1063. [CrossRef] [PubMed]

100. Colella, D.; Guerra, A.; Paparella, G.; Cioffi, E.; Di Vita, A.; Trebbastoni, A.; Berardelli, A.; Bologna, M. Motor dysfunction in mild cognitive impairment as tested by kinematic analysis and transcranial magnetic stimulation. Clin. Neurophysiol. 2021, 132, 315-322. [CrossRef] [PubMed]

101. Cabeza, R.; Albert, M.; Belleville, S.; Craik, F.I.M.; Duarte, A.; Grady, C.L.; Lindenberger, U.; Nyberg, L.; Park, D.C.; Reuter-Lorenz, P.A.; et al. Maintenance, Reserve and Compensation: The Cognitive Neuroscience of Healthy Ageing. Nat. Rev. Neurosci. 2018, 19, 701-710. [CrossRef] [PubMed]

102. Roe, C.M.; Xiong, C.; Miller, J.P.; Morris, J.C. Education and Alzheimer disease without dementia: Support for the cognitive reserve hypothesis. Neurology 2007, 68, 223-228. [CrossRef]

103. Groot, C.; Van Loenhoud, A.C.; Barkhof, F.; Van Berckel, B.N.; Koene, T.; Teunissen, C.C.; Scheltens, P.; Van Der Flier, W.M.; Ossenkoppele, R. Differential effects of cognitive reserve and brain reserve on cognition in Alzheimer disease. Neurology 2017, 90, e149-e156. [CrossRef]

104. Marvel, C.L.; Morgan, O.P.; Kronemer, S.I. How the motor system integrates with working memory. Neurosci. Biobehav. Rev. 2019, 102, 184-194. [CrossRef]

105. Michely, J.; Volz, L.; Hoffstaedter, F.; Tittgemeyer, M.; Eickhoff, S.; Fink, G.; Grefkes, C. Network connectivity of motor control in the ageing brain. NeuroImage Clin. 2018, 18, 443-455. [CrossRef]

106. Salzman, T.; Aboualmagd, A.; Badawi, H.; Tobón-Vallejo, D.; Kim, H.; Dahroug, L.; Laamarti, F.; El Saddik, A.; Fraser, S. Prefrontal Cortex Involvement during Dual-Task Stair Climbing in Healthy Older Adults: An fNIRS Study. Brain Sci. 2021, 11, 71. [CrossRef] [PubMed]

107. Albers, M.W.; Gilmore, G.C.; Kaye, J.; Murphy, C.; Wingfield, A.; Bennett, D.A.; Boxer, A.L.; Buchman, A.S.; Cruickshanks, K.J.; Devanand, D.P.; et al. At the interface of sensory and motor dysfunctions and Alzheimer's disease. Alzheimer's Dement. 2015, 11, 70-98. [CrossRef] [PubMed]

108. Aggarwal, N.T.; Wilson, R.S.; Beck, T.L.; Bienias, J.L.; Bennett, D.A. Motor Dysfunction in Mild Cognitive Impairment and the Risk of Incident Alzheimer Disease. Arch. Neurol. 2006, 63, 1763-1769. [CrossRef] [PubMed]

109. Scarmeas, N.; Albert, M.; Brandt, J.; Blacker, D.; Hadjigeorgiou, G.; Papadimitriou, A.; Dubois, B.; Sarazin, M.; Wegesin, D.; Marder, K.; et al. Motor signs predict poor outcomes in Alzheimer disease. Neurology 2005, 64, 1696-1703. [CrossRef]

110. Camicioli, R.; Licis, L. Motor impairment predicts falls in specialized Alzheimer care units. Alzheimer Dis. Assoc. Disord. 2004, 18, 214. [PubMed] 
111. Ansai, J.H.; De Andrade, L.P.; Masse, F.A.A.; Gonçalves, J.; Takahashi, A.C.D.M.; Vale, F.A.C.; Rebelatto, J.R. Risk Factors for Falls in Older Adults With Mild Cognitive Impairment and Mild Alzheimer Disease. J. Geriatr. Phys. Ther. 2019, 42, E116-E121. [CrossRef] [PubMed]

112. Ehsani, H.; Parvaneh, S.; Mohler, J.; Wendel, C.; Zamrini, E.; O'Connor, K.; Toosizadeh, N. Can motor function uncertainty and local instability within upper-extremity dual-tasking predict amnestic mild cognitive impairment and early-stage Alzheimer's disease? Comput. Biol. Med. 2020, 120, 103705. [CrossRef]

113. Dubois, B.; Albert, M.L. Amnestic MCI or prodromal Alzheimer's disease? Lancet Neurol. 2004, 3, 246-248. [CrossRef]

114. Chang, K.-V.; Hsu, T.-H.; Wu, W.-T.; Huang, K.-C.; Han, D.-S. Association Between Sarcopenia and Cognitive Impairment: A Systematic Review and Meta-Analysis. J. Am. Med. Dir. Assoc. 2016, 17, 1164.e7-1164.e15. [CrossRef]

115. Morris, R.; Lord, S.; Bunce, J.; Burn, D.; Rochester, L. Gait and cognition: Mapping the global and discrete relationships in ageing and neurodegenerative disease. Neurosci. Biobehav. Rev. 2016, 64, 326-345. [CrossRef]

116. Marquis, S.; Moore, M.M.; Howieson, D.B.; Sexton, G.; Payami, H.; Kaye, J.A.; Camicioli, R. Independent predictors of cognitive decline in healthy elderly persons. Arch. Neurol. 2002, 59, 601-606. [CrossRef]

117. Chou, M.-Y.; Nishita, Y.; Nakagawa, T.; Tange, C.; Tomida, M.; Shimokata, H.; Otsuka, R.; Chen, L.-K.; Arai, H. Role of gait speed and grip strength in predicting 10-year cognitive decline among community-dwelling older people. BMC Geriatr. 2019, 19, 1-11. [CrossRef] [PubMed]

118. Clegg, A.; Young, J.; Iliffe, S.; Rikkert, M.O.; Rockwood, K. Frailty in elderly people. Lancet 2013, 381, 752-762. [CrossRef] 